\title{
PERAN ORANG TERDEKAT REMAJA PUTRA TERHADAP PERILAKU SEKSUAL PRANIKAH (ANALISIS DATA SDKI KRR 2017)
}

\author{
Agustina utii ${ }^{1}$, Priscilla Jessica Pihahey ${ }^{2}$ \\ ${ }^{1-2}$ Mahasiswa Pasca Sarjana Ilmu Kesehatan Masyarakat Universitas Sebelas Maret Indonesia \\ ${ }^{2}$ Poltekkes Kemenkes Sorong Papua Barat \\ Email: agustinautii1@gmail.com \\ pihaheypriscilla@gmail.com
}

\begin{abstract}
ABSTRAK
Perilaku seks pranikah pada remaja semakin meningkat, salah satu faktornya adalah akses tanpa batas terhadap media sosial, dan internet. Meskipun pengaruh positif diperoleh dengan semakin mudahnya infornasi dampak negatif adalah informasi yang diperoleh jika tidak valid mempengaruhi pengetahuan dan menjadi referensi untuk bertindak dengan salah. Untuk itu dengan segala dampak dari seks pranikah baik penyakit menular, pernikahan dini, kelahiran yang tidak diinginkan dapat diatasi dengan peran orang terdekat remaja yaitu orang tua teman dan saudara kandung. Populasi dan sampel adalah remaja usia 14-24 tahun berjenis kelamin laki-laki dan belum menikah atau tinggal Bersama. Variabel dependen remaja pria yang telah melakukan seks pranikah dan variabel independen status pacaran, dan peran orang terdekat dalam memberikan informasi kesehatan reproduksi. Desain penelitian ini adalah cross sectional dan model analisis regresi logistik untuk melihat seberapa besar pengaruh variabel dependen terhadap independen. Hasil penelitian menunjukkan resiko meningkat terhadap status pacarana $(\mathrm{OR}=4.29$; CI 95\% 3.77 - 4.88: $\mathrm{p}=0.000)$, peran teman meningkatkan risiko $(\mathrm{OR}=1.26$; CI 95\% 1.11-1.42: $\mathrm{p}=0.000)$, peran Ibu menurunkan resiko $(\mathrm{OR}=0.88$; CI 95\% 0.681.13: $\mathrm{p}=0.328)$, Peran Ayah meningkatkan ( $\mathrm{OR}=1.02$; CI 95\% 0.78-1.33: $\mathrm{p}=0.859)$, Peran saudara kandung (OR $=1.58$; CI 95\% 1.32-1.89: $\mathrm{p}=0.00)$. Kesimpulan peran keluarga dalam perilaku seks remaja pria bisa meningkatkan resiko apabila tidak memberikan melakukan komunikasi tentang kesehatan reproduksi dan didukung oleh status memiliki pacar.
\end{abstract}

Kata Kunci: Remaja Pria, Seks Pranikah, Peran Keluarga, Status Berpacaran 


\begin{abstract}
Premarital sexual behavior in adolescents is increasing, one of the factors is unlimited access to social media, and the internet. Although the positive influence is obtained by the more easily information negative impact is information obtained if it invalidly affects knowledge and becomes a reference for acting wrong. For this reason, with all the effects of pre-marital sex, both infectious diseases, early marriages, unwanted births can be overcome by the role of those closest to teenagers, namely parents, friends and siblings. Popiulation and samples are teenagers aged 14-24 years, male and not married or living together. The dependent variable is male adolescents who have had premarital sex and the independent variable is girlfriend status, and the role of the closest people in providing reproductive health information. The design of this study is cross sectional and logistic regression analysis models to see how much influence the dependent variable has on the independent. The results showed an increased risk of girlfriend status $(O R=4.29 ; 95 \%$ CI $3.77-4.88: p=0.000)$, the role of friends increased risk $(O R=1.26 ; 95 \% C I$ 1.11-1.42: $p=0.000)$, the mother's role reduced the risk $(O R=0.88 ; 95 \%$ CI 0.68-1.13: $p=0.328)$, Father's role increases $(O R=1.02 ; 95 \%$ CI 0.78-1.33: $p=0.859)$, Sibling's role $(O R=1.58 ; 95 \%$ CI 1.32- 1.89: $p=0.00)$. Conclusion perankelamily in adolescent male sexual behavior can increase the risk if it does not provide communication about reproductive health and is supported by the status of having a boyfriend.
\end{abstract}

Keywords: Young man, Premarital sex, Family roles, Dating status, 


\section{LATAR BELAKANG}

Remaja merupakan siklus yang penting dalam kehidupan manusia, karena sebagian masalah kesehatan reproduksi pada usia dewasa sampai lanjut usia disebabkan oleh perilaku pada usia remaja. Perilaku beresiko pada usia remaja antara lain adalah seks bebas, narkoba, minuman keras, merokok, pernikahan dini,aborsi, tawuran, pencurian, kenakalan remaja, dan sebagainya.

Remaja adalah masa pada saat individu berkembang dari pertama kali menunjukkan tanda-tanda sosial seksual sekundernya sampai saat mencapai kematangan seksual. Individu berkembang dari sisi psikologis dan pola identifikasi dari kanak- kanak menjadi dewasa. Terjadi peralihan dari ketergantungan sosial- ekonomi yang penuh pada keadaan yang relatif lebih mandiri ( Sarwono 2007, dalam Wahyuni and Fahmi, 2017)

Litbang Kesehatan berasama UNESCO melaporkan hasil survey 5,6 \% remaja di Indonesia telah melakukan seks pranikah (Bkkbn, 2018). Perilaku seksual didefinisikan sebagai segala tindakan yang dipicu oleh hasrat seksual baik lawan jenis maupun sejenis. Remaja yang telah sekali melakukan hubungan seks kemungkinan akan melakukannya kembali baik dengan pasanagan yang sama atau yang berbeda. (Adilah, Mutahar and Sari, 2017). Remaja dengan jenis kelamin laki-laki yang telah melakukan $\mathrm{h}$ ubungan seks 3,6 \% berumur 15-19 tahun dan 14,0 \% umur 20-24 tahun. Alasan para remaja ini cukup beragam dianataranya saling cinta $46,1 \%$,terjadi begitu saja $14,4 \%$ dan rasa ingin tahu atau coba-coba $34 \%$ dari jumlah total remaja . Keadaaan ini sangat memprihatinkan mengingat pemerintah telah melakukan berbagai program untuk memberikan lebih banyak informasi kepada remaja tentang kesehatan reproduksi, penyakit menular seksual, HIV/AIDS, pernikahan dini, dan penundaan usia perkawinan.

Informasi begitu mudah didapatkan melalui berbagai media elektronik, media cetak, poster, papan himbauan, iklan-iklan dengan pesan positif, namun tetap saja kemudahan memperoleh informasi ini memberikan dampak negatif jika tidak di kontrol. Ada begitu banyak konten pornografi yang dapat diakses lewat internet melalui media sosial tentu saja ini memberikan pengaruh untuk meningkatkan aktifitas seksual pada remaja. Pemerintah juga telah memberikan pembelajaran kepada remaja sejak dini melalui pendidikan di bangku sekolah, dengan harapan mempersiapkan para remaja untuk memiliki perencanaan akan masa depan dengan memilki banyak pengetahuan. Pengetahuan yang di berikan diharapkan menjadi sumber informasi yang akurat saat membuat keputusan akan berhubungan seksual setelah menikah ataukah sebelum.

Tujuan penelitian ini untuk melihat seberapa besar pengaruh orang terdekat yaitu : teman, ayah, ibu dan saudara kandung serta status pacarana dari remaja pria tentang kesehatan reproduksi terhadap perilaku seks pranikah pada remaja pria di Indonesia berdasarkan analisis data SDKI 2017.

\section{METODE PENELITIAN}

Penelitian ini menggunakan definisi remaja mengikuti Survey Demografi dan Kesehatan Indonesia Kesehatan Reproduksi Remaja Tahun 2017, data sekunder diakses melalui http://sdki.bkkbn.go.id/. Sampel yang di gunakan adalah remaja merupakan pria berumur 15-24 tahun yang belum kawin/ hidup bersama. Analisis ini menggunakan raw data hasil SDKI KRR 2017 dengan responden remaja pria berumur 15-24 tahun berjumlah 13.079 pria dan status belum kawin/hidup bersama .

Variabel dependen adalah remaja pria yang telah melakukan seks pranikah sejumlah 1.333 remaja dari 33 provinsi. Variabel independen yaitu faktor internal meliputi pendidikan terakhir, teman, ayah, ibu, saudara kandung, keluarga tentang kesehatan reproduksi. Faktor eksternal yaitu tempat tinggal, peran tenaga kesehatan, guru, tokoh agama, dan yang 
menjawab semua pertanyaan pada variabel bebas. Data yang sudah didapatkan perlu dilakukan proses editing, coding, tabulasi dan pengecekan missing data. Data di analisis secara univariat, bivariat, dan multivariat dengan analisis regresi logistik.

\section{HASIL DAN PEMBAHASAN}

Tabel 1

Karakteristik Sampel

\begin{tabular}{llcc}
\hline Karakteristik & Category & Frequency & Percentage \\
\hline \multirow{4}{*}{ Pendidikan } & SD & 1,273 & 9.73 \\
& SMP & 2,135 & 16.32 \\
& SMA & 7,662 & 58.58 \\
& DI/DII/DIII & 281 & 2.15 \\
\multirow{2}{*}{ Seks Pranikah } & DIV/Universitas & 1,728 & 13.21 \\
& Melakukan & 1.333 & 10.19 \\
Status Pacaran & Tidak & 11.602 & 88.71 \\
& Melakukan & 7.363 & 56.30 \\
& Ya & 5.716 & 43.70 \\
\hline
\end{tabular}

Tabel 1 menggambarkan sampel remaja pria yang telah melakukan seks pranikah sebanyak 1.333 ( $10.19 \%$ ) ada peningkatan dari hasil penelitian SDKI tahun 2012 yang oleh Puspasari et all (2012) yang melaporkan hasil remaja pria dan wanita yang melakukan seks pranikah sebanyak 733 remaja $(7.37 \%)$. Remaja pria yang berpacaran 7.363 (56.30\%), dengan Pendidikan terakhir terbanyak adalah SMA sejumlah 7.662 remaja.

Tabel 2

Analisis bivariat faktor peran keluarga dalam kesehatan reproduksi remaja pria

\begin{tabular}{|c|c|c|c|c|c|c|}
\hline \multirow{3}{*}{$\begin{array}{l}\text { Variabel } \\
\text { Independent }\end{array}$} & \multicolumn{4}{|c|}{ Remaja Pria Seks Pranikah } & \multirow[t]{3}{*}{ Total } & \multirow[t]{3}{*}{$p$-Value } \\
\hline & \multicolumn{2}{|c|}{ Melakukan } & \multicolumn{2}{|c|}{ Tidak Melakukan } & & \\
\hline & $\mathbf{n}$ & $\%$ & $\mathbf{n}$ & $\%$ & & \\
\hline \multicolumn{7}{|l|}{ Teman } \\
\hline Ya & 809 & 60.69 & 6.049 & 51.50 & 6.858 & 0.000 \\
\hline Tidak & 524 & 39.31 & 5697 & 48.50 & 6.221 & \\
\hline Ibu/ Mama & & & & & & 0.078 \\
\hline Ya & 162 & 12.15 & 1.242 & 10.57 & 1.404 & \\
\hline Tidak & 1.171 & 87.85 & 10.504 & 89.43 & 11.675 & \\
\hline Ayah & & & & & & 0.016 \\
\hline Ya & 141 & 10.58 & 1.010 & 8.60 & 1.151 & \\
\hline Tidak & 1.192 & 89.42 & 10.736 & 91.40 & 11.928 & \\
\hline \multicolumn{7}{|c|}{ Saudara Kandung } \\
\hline Ya & 224 & 16.80 & 1.189 & 10.12 & 1.413 & 0.000 \\
\hline Tidak & 1.109 & 83.20 & 10.557 & 89.88 & 11.666 & \\
\hline
\end{tabular}


Table 2 menunjukkan tabulasi silang antara variabel remaja yang telah melakukan seks pra nikah dengan peran orang terdekat yaitu ayah,ibu, saudara kandung dan teman sebagai sumber informasi kesehatan reproduksi. Ada pengaruh signifikan antara remaja yang sering membicarakan hal reproduksi dengan teman $60.69 \%$ dan saudara kandung $16.80 \%$ Sedangkan tidak ada pengaruh signifikn antara peran Ayah dan Ibu terhadap perilaku seks pra remaja. Hasil penelitian ini selaras dengan Umaroh et all (2015) bahwa terdapat hubungan yang signifikan antara peran yang baik orang terdekat seperti teman, ibu, ayah, saudara,guru, petugas kesehatan, terhadap perilaku seksual pranikah remaja $(p=0,000)$.

Tabel 3

Hasil Analisis Regresi Logistic

\begin{tabular}{|c|c|c|c|c|}
\hline \multirow[b]{2}{*}{ Independent Variables } & \multirow[b]{2}{*}{ OR } & \multicolumn{2}{|c|}{ CI (95\%) } & \multirow[b]{2}{*}{$\mathbf{p}$} \\
\hline & & Lower Limit & Upper Limit & \\
\hline Status Pacaran & 4.29 & 3.77 & 4.88 & 0.000 \\
\hline Peran Teman & 1.26 & 1.11 & 1.42 & 0.000 \\
\hline Peran Ibu & 0.88 & 0.68 & 1.13 & 0.328 \\
\hline Peran Ayah & 1.02 & 0.78 & 1.33 & 0.859 \\
\hline Peran saudara Kandung & 1.58 & 1.32 & 1.89 & 0.000 \\
\hline $\begin{array}{l}\text { N. Obs }=13.079 \\
\text { Adj R-Squared }=0.07 \\
\text { p }<0.000 \\
\text { Log Likelihoo }=-3987.12\end{array}$ & & & & \\
\hline
\end{tabular}

Hasil regresi logistik menunjukkan remaja pria yang melakukan hubungan sex pranikah dengan status berpacaran signifikan. Remaja pria yang berpacaran risiko melakukan hubungan seks pranikah 4.29 kali dibanding yang tidak berpacaran . Hasil berbeda dengan penelitian oleh Susanti dan Widyoningsih (2019) yang melaporkan hasil tidak ada hubungan signifikan antara seks bebas dengan status berpacaran, perbedaan ini bisa dipengaruhi oleh perbedaan besarnya sampel dan status remaja yang tidak berpacaran.

Peran keluarga dalam memberikan informasi kesehatan reproduksi juga mempengaruhi remaja pria dalam aktivitas seksualnya. Remaja yang tidak pernah bercerita, bertanya, atau meminta pendapat tentang kesehatan reproduksinya cenderung melakukan hubungan seks pranikah. Hasil analisis data menunjukkan peran masing-masing orang terdekat secara terpisah. Hasil penelitian yang sama oleh Umaroh et all.,( 2015) menunjukan bahwa remaja yang memiliki hubungan baik dengan orang terdekat yang peran baik dalam hal berbagi informasi kesehatan reproduksi $80.5 \%$ tidak melakukan seks pranikah. hasil penelitian ini menunjukkan peran teman sebagai tempat bertukar informasi kesehatan reproduksi signifikan . Artinya teman memiliki peran penting bagi remaja, informasi yang salah dari teman bisa berdampak pada perilaku menyimpan. Remaja pria yang lebih banyak bercerita kepada teman memiliki kemungkinan melakukan seks pranikah sebesar 1.26 kali dibanding yang tidak.

Kehidupan remaja yang penuh gejolak, keingintahuan, berdapak positif dan negatif pada perilaku seksual. Dengan semakin mudahnya akses informasi melalui media sosial dan 
internet, memungkinkan remaja mencari informasi sendiri tanpa melihat bukti atau fakta pendukung suatu informasi. Remaja yang dekat dengan ayah atau ibu dan sering bertanya tentang hal kesehatan reproduksi ternyata secara statistik tidak berhubungan. Peran ibu sangat penting sebagai Pendidikan anak remaja, secara psikologis hubungan anak dan ibu lebih dekat dibandingkan ayah. Remaja akan cenderung mengajukan pertanyaan seputar perubahan dalam hidup kepada ibu dibandingkan ayah.

Komunikasi interpersonal antara orang tua dan remaja meliputi keterbukaan, empati, sikap positif, kesetaraan anak-anak dalam keluarga, sangat berperan penting terhadap perilaku seks pranikah pada remaja (Beniar, Harmin and Ridwan, 2019). Keterbukaan dalam memberikan informasi membuat remaja tidak takut atau ragu-ragu ketika berbicara tentang kesehatan reproduksinya termasuk perilaku seks. Empati dari orang tua memberikan kesempatan kepada remaja untuk menceritakan persoalan yang dihadapi. Namun dalam kenyataannya orang tua sering kali berkomunikasi dengan anak remaja cenderung proktektif, hal ini menyebabkan remaja tidak terbuka dalam hal berbicara. Hasil penelitian ini menunjukkan peran ayah dan ibu secara berbeda respoden yang melakukan seks pranikah tidak hanya $12.15 \%$ yang bertanya tentang kesehatan reproduksi kepada ibu dan kepada ayah $10.58 \%$. Remaja berkomunikasi tentang kesehatan reproduksi kepada ibunya memiliki risiko 0.88 lebih rendah. Responden yang tidak membicarakan seks pranikah kepada ayahnya memilki resiko 1.02 kali melakukan seks.

Bagaimana peran saudara kandung dalam hal ini bisa remaja cenderung lebih akrab dengan saudara kandung. Kemungkinan untuk bercerita dan meniru perilaku kesehatan lebih besar dibandingkan dengan teman dan keluarga lainnya. Hasil penelitian ini menunjukan 83. $20 \%$ remaja yang melakukan seks tidak berkomunikasi kepada saudara kandung tentang kesehatan reproduksi. Pengaruh ini meningkatkan risiko seks pranikah 1.06 kali dibandingkan dengan remaja yang sering bercerita.

Penelitian ini sejalan dengan penelitian Mariani dan Murtadho (2018) yang menyimpulkan memiliki peran orang tua yang baik, teman sebaya, sikap positif terhadap kesehatan reproduksi mempengaruhi perilaku beresiko seks pranikah.

\section{SIMPULAN DAN SARAN}

\section{Simpulan}

1. Status berpacaran meningkatkan seks pranikah 4.29 kali dari pada remaja pria yang tidak memiliki pacar.

2. Perilaku seks pranikah dikalangan remaja pria meningkat dengan risiko 1.26 kali ketika lebih banyak medapatkan informasi dan bertukar pikiran mengenai kesehatan reproduksi kepada teman.

3. Meskipun pengaruh peran ayah dan ibu tidak signifikan secara statistik, tetapi risiko seks pranikah lebih rendah 0.08 ketika remaja melibatkan ibu dalam hal kesehatan reproduksi.

4. Peran saudara kandung terhadap perilaku kesehatan reproduksi sebagai orang terdekat persentase kejadian seks pra nikah $83.20 \%$ adalah pada remaja yang tidak pernah berdiskusi tentang kesehatan reproduksi.

\section{Saran}

1. Peran orang terdekat untuk mengatasi masalah remaja sangat berpengaruh, oleh karena itu dalam lingkungan keluarga perlunya orang tua meluangkan waktu bersama remaja, berkomunikasi tentang masalah yang di hadapi remaja. 
2. Program pendidkan kesehatan reproduksi kepada remaja perlu dilakukan bersama-sama dengan anggota keluarga, sehingga dapat memberikan manfaat sebesar-besarnya kepada remaja dengan tidak terjadi kejanggungan antara keluarga dan remaja.

\section{UCAPAN TERIMAKASIH}

Terimakasih kepada Kementrian Kesehatan RI, BPS, BKKBN yang telah memberikan ijin untuk memanfaatkan data sekunder hasil Survey Demografi dan Kesehatan khususnya Kesehatan Reproduksi Remaja Tahun 2017.

\section{DAFTAR PUSTAKA}

Adilah, Y., Mutahar, R. and Sari, I. P. (2017) 'Determinan Penggunaan Kondom pada Hubungan Pertama Kali oleh Remaja Belum Menikah di Indonesia ( analisis Data SDKI KRR 2012)', 8(2), pp. 91-99.

Beniar, Harmin, S. and Ridwan, H. (2019) 'Komunikasi Interpersonal Orang Tua Dan Anak Remaja Dalam Mencegah Perilaku Seks Pranikah Di Kelurahan Watu-Watu Kecamatan Kendari Barat Kota', Jurnal Ilmu Komunikasi UHO: Jurnal Penelitian Kajian Ilmu Komunikasi dan Informasi, 4(1), pp. 1-17.

Bkkbn (2018) Survei Demografi dan Kesehatan Indonesia, Administrator SDKI. http://sdki.bkkbn.go.id/?lang=id\&what=news-detail\&id=9\&type=news (Akses: 3 November 2019).

Mariani, N. N. and Murtadho, S. F. (2018) 'Peran Orang Tua, Pengaruh Teman Sebaya, Dan Sikap Berhubungan Dengan Perilaku Seksual Pranikah Pada Siswa-Siswi SMA Negeri 1 Jamblang Kabupaten Cirebon', 6(2), pp. 116-130.

Puspasari, Sukamdi and Emilia, O. (2012) 'Paparan informasi kesehatan reproduksi melalui media pada perilaku seksual pranikah: analisis data survei demografi kesehatan Indonesia 2012', Berita Kedokteran Masyarakat, 33(1), pp. 31-36.

Susanti and Widyoningsih (2019) 'Faktor -Faktor Yang Mampengaruhi Sikap Remaja', Jurnal Ilmu Keperawatan dan Kebidanan, 10(2), pp. 297-302.

Umaroh, A. K., Kusumawati1, Y. and Kasjono, H. S. (2015) 'Hubungan antara faktor Internal dan Faktor Eksternal Dengan Perilaku Seksual Pranikah Remaja Di Indonesia', Jurnal Kesehatan Masyarakat Andalas, 10(1), pp. 65-75.

Wahyuni, S. and Fahmi, I. (2017) 'Determinan Perilaku Seksual Pra Nikah Remaja Pria di Indonesia Hasil SDKI', 6(2), pp. 177-188. 